\title{
Historein
}

Vol $10(2010)$

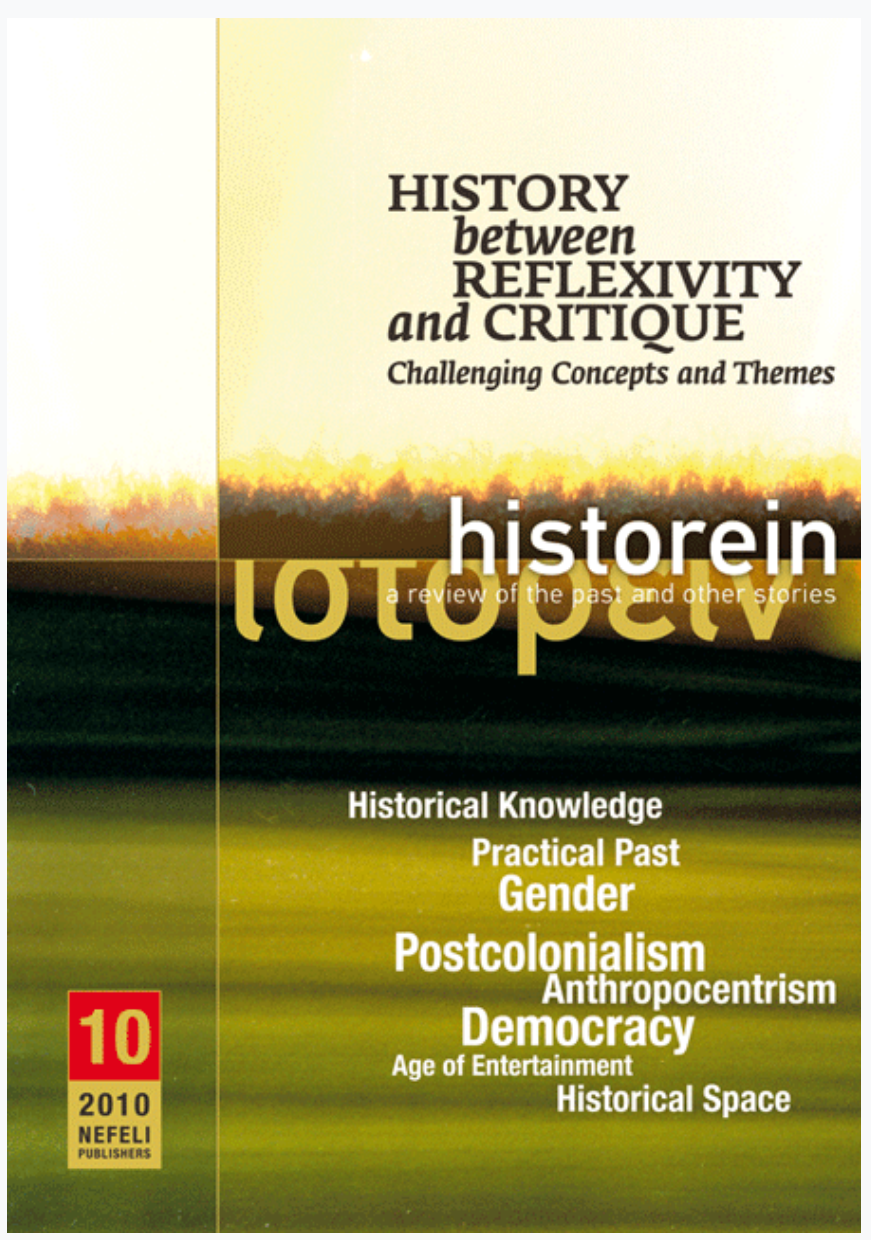

\section{Critical Historiography in the Entertainment Age}

Kalle Pihlainen

doi: $\underline{10.12681 / \text { historein.10 }}$

and CRITIQUE

do.12681/historein.10

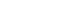

History between Reflexivity and Critique 
Critical During the last decade or so, there has been mounting dissatisfaction with the ex-

\section{Historiography}

in the

\section{Entertainment Age}

Kalle Pihlainen

Åbo Akademi University/

Academy of Finland tremes of the linguistic turn. The kind of "textualism" derived from literary theory readings of Derrida (most famously by the "Yale school") that subscribe to "the endless play of signifiers" with no contact point beyond language - that, to use the words of Mark Bevir, deny even "a provisional halt to the process of interpretation"1 - seems ill-suited to historical studies. Even more moderate appeals to textualism seem to introduce as many problems as they solve. Following the overwhelming acceptance of the "linguistic turn" in historical theory, history has increasingly come to be viewed as a second-order literary pursuit (think especially of readings of Hayden White's and Keith Jenkins' work); the conclusion for many is that history is a form of literary creation for the less talented. History is thus less often set in opposition against literature (the opposition of fact and fiction) than it is compared to it when discussing the finer points of particular representational strategies assumed. ${ }^{2}$ Hence, perhaps, the practical or "historical turn", ${ }^{3}$ or even an "empirical turn", ${ }^{4}$ by those more historically minded. In this situation, one of the main challenges in historical theory is to retain the achievements of the linguistic turn concerning ideology and power while defining what history's particular role and legitimate applications might be - without ending up with a valorisation of endless interpretations or the return to naive empiricism. Success in this might help salvage history from both servitude to ideology and complete meaninglessness. Of course, this is not a task for theorists alone. 
In his final chapter to In 1926 - nicely entitled "After Learning from History" - Hans Ulrich Gumbrecht notes that it is time "at least for professional historians, to respond seriously to a situation in which the claim that 'one can learn from history' has lost its persuasive power". ${ }^{5} \mathrm{He}$ continues: "To respond seriously to this change would mean that professional historians ... would have to begin thinking about its consequences - without being apologetic, and without feeling obliged to prove wrong those who, never expecting to learn from history, have no use for all the knowledge about the past that we preserve, publish and teach." Responding "seriously" in this way to the abandonment of history's didactic function as justification for "doing history" is a challenge that should unite historians and theorists rather than create dissent. How, after all, can either group neglect the fact that history continues to be produced and consumed with no other remaining justifications than its institutional position and its utility as a pastime? Certainly rescuing history by redefining its purpose has been the driving force behind the work of many contemporary theorists (most notably, I would say, Hayden White, despite some interpretations to the contrary). ${ }^{6}$

So, why history?

If nothing else, the questions "Why history?" or "What is history for?" can provide justification for contemporary historical theory: if we were to assume a thoroughly empiricist, "objective" approach to history, the question might easily appear superfluous. History could simply be justified in terms of its telling us things about the past that would reveal how things really were and thus, on top of providing answers to questions regarding causes and effects as well as explanations for various phenomena, show us how we might better conduct ourselves in order to achieve or avoid whatever situations we find desirable or undesirable. History would be able to teach us essential lessons about the world and its pragmatic occupation.

While we (that is most historians and theorists) have successfully distanced ourselves from the speculative history dimension of claims regarding history's lessons, these old sentiments do seem to persist even in so-called lower-case, avowedly objectivist histories. They cause, moreover, continuing difficulties: for those of us who embrace the provisional and constructed nature of historical interpretation, the question of history's purpose gives occasion for "presentist" speculation. And this is perceived - correctly - as hostile to empiricist, institutionally dominant historical research. In other words, as long as empiricism is seen as a cure-all for contrived, linguistically plagued theories, saying that history provides knowledge that can be used for social purposes is perfectly acceptable. Saying the same thing while doubting the infallibility of history makes the claim suspect even for hardline empiricists, however. Indeed, it appears that history cannot be used in identical ways if one's beliefs regarding it are different. This may simply be a matter of the way "the political" is introduced into the equation; the unsavoury flavour brought by the use of instrumental terms; 


\section{Critical Historiography in the Entertainment Age}

as in the insistence that we need to use history rather than simply allow "truth" to speak for itself.

Of course, there are also more credible arguments than the worn-out "those who do not know history are doomed to repeat it", for instance: history encourages self-reflection. Or, history provides us with opportunities to experience vicariously things not present in our life-worlds. These are the kinds of arguments where the concreteness of the past and its representations seem to offer at least some privilege. And they are the ones, I think, to try to run with.

But then the question becomes: what of literature and film, for instance? Why reject the claim that other imaginaries can provide the same "knowledge" without the discomfort incurred by his-

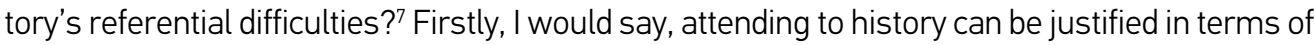
the strength of the historical imagination in some people as well as the way in which the concreteness of the past can compel self-reflection in a different register to encounters with the "merely" imaginary. And secondly: in addition to lending support to the status quo, history can also provide a space for critique. The bracketing of "real" reference too easily turns us from the world to ourselves, from "politics" (serious engagement) to entertainment. I will examine this issue of critique first.

As I see it, there are two main obstacles to critical historiography. The first is the traditional emphasis on "objectivity" and "science". On this view, history should not be rhetorical or political but should rather exhibit openness to its subject of study, research conducted in a spirit of objectivity ensured by rigid methodological strictures. (This question has been so much debated already that I won't attempt to say much about it here.) The second, equally insidious, obstacle comes quite paradoxically from attempts at tempering the extremes brought by viewing history as science in this strict way. This second obstacle to critical historiography lies in the so-called universalisation of difference - in epistemological relativism as expanded and accepted to the extent that no positions can be unproblematically endorsed over others. Here historical representation has come to be seen as thoroughly rhetorical and political, and all noninstitutional, nonpolitical grounds for determining its value have been rejected. This is what I like to call our "turn" to entertainment.

It seems to me that this second difficulty is the one that currently warrants the attention of historical theory. After all, the debate over objectivity has arrived at a deadlock, with both historians and theorists simply reiterating familiar positions.

Importantly, I believe, the turn to entertainment has been inspired more by the refusal of theory to offer prescriptive rules for historians to follow than by the critique of objectivity. Yet there is an obvious reason for this reticence to prescribe. The only way to continue the line of argument that constructivism sets us on in a prescriptive way is to abandon history as a specific form of knowledge and turn it into trope, language, rhetoric, literature, politics and so on. Abandoning the scientific aspiration of history in this way results in admitting that it is just another imagi- 
nary, a tool for shaping the world in ways that have subjective appeal for a particular historian. So, are there no mediating positions to be had? Of course there are, but no fully comfortable ones in terms of systematic argumentation: The only way to escape from this either-or is to relinquish the need for system and accept the "outsideness" of morality to science in the way done by Richard Rorty and Jacques Derrida, for example. (In this way, poststructuralist philosophy gets around the problem by presenting its ethics on pragmatic rather than philosophical grounds.) Obviously there is no absolute way to justify a particular ethical or political choice; thus, what is important to realise is that the demand for such justification within science is a needless one. In history, this point, too, has been well-argued in the work of Hayden White, Frank Ankersmit and Keith Jenkins, to name just a prominent few. ${ }^{8}$

To arrive at any functioning history that does not adopt either the extreme of "objective science" or that of "history as fiction", theoretical discomfort must be endured. Only in this discomfort can critical historiography be discovered.

Critical historiography obviously has a market and demand today. Think of the reception of Michael Moore's documentary films, for example; interestingly, the differences between such "infotainment" and the kinds of interventions in historical representation that Hayden White calls for in his essay on the "modernist event" appear nonexistent. ${ }^{9}$ Even the temporal distance that historians traditionally demanded between observer and the observed event has been erased in contemporary practice within institutional historiography - indeed, even more so here than in popular forms, perhaps, since "history" still means the distant past in popular conceptualisations whereas current historiography seems to be increasingly concerned also with more recent phenomena.

Yet, how justified is my claim concerning a "turn" to entertainment? Is there any point in saying that we presently live in an "entertainment age"? Understood in terms of irony regarding truth, even at the highest levels, it certainly seems to be quite an accurate representation. Ascertaining truth does not appear to be a central goal for politics, for example. Instead, for many, there is a focus on effects - we already believe we have a sufficient grasp of how things are and the aim is to implement a particular personal vision in and onto the world. Speaking of this in terms of entertainment may seem callous, but that is not my intention. The reference to entertainment is, rather, a reference to some of the ways in which we interact with the world: the expectation of quick gratification, the ease with which rhetoric defeats the withholding of judgement, the unassailability of subjective beliefs, and so on. Most centrally, the reference to entertainment is meant to signify the kind of attitude where justification and approval for one's actions are more important than the reasons for them. Public intentions thus become more important than actual goals or effects.

For immediate purposes, this kind of interpretation of publicity and attention to effects serves to highlight an interesting transformation within history and historical theory: where the original 


\section{Critical Historiography in the Entertainment Age}

emphasis of linguistic constructivism was clearly political in that it provided a means to question authoritative interpretations when necessary, the more avant-garde branches of constructivist theorising and "historicising" now focus on the ways in which representation can create experience - in other words, on the extent to which it can stimulate and entertain. Now, this is not to say that the creation of emotional involvement in readers or viewers is unimportant - far from it. Rather, the intention is to point out that the original critical motivation behind the emphasis on history as involving literary creation has been lost in some areas (while the whole debate is stubbornly refused in others, of course): instead, the goal de jour has been to make "history" more appealing in form; more appealing for consumption as opposed to reflection. Experimentation has been fuelled as much (and in some cases more) by innovative forms and subject matter being perceived as values in themselves, as by the desire to rethink history specifically as history. Of course, this is still not necessarily a bad thing since results are more important than intentions in defining institutional change of this kind - in other words, in redefining what history is.

Indeed, there are even benefits to be had from making history sexier. If it fails to interest and involve readers, there is little point to it in terms of critical engagement. Again, infotainment serves well to illustrate the benefits to be had from this kind of appeal. At the same time, if the emphasis on textualism and entertaining is taken too far and history is seen as only one imaginary among others, its status as at least aspiring to knowledge ("knowledge" understood in a postfoundational sense, of course) is compromised and its value as critique is undermined to much the same extent. Another benefit - albeit again subject to much theoretical discomfort - is the way it allows us to devote attention to the dimension of experience.

Drawing attention to the issue of experience, Gumbrecht writes:

[W] hat could be the point of so much insistence on the unbridgeable distance that separates us from past worlds if it were not the desire to re-present - to make present again - those past worlds? Historical culture cannot avoid living between its endeavor to fulfill such desire for presence and an awareness that this is an impossible self-assignment ... Yet as soon as historical culture openly opts for this desire for re-presentation ... it cannot help being ironic, for it then re-presents the past as a "reality" though it knows that all re-presentations are simulacra. ${ }^{10}$

Yet Gumbrecht's solution seems too limited. While he quite rightly turns attention to the motivation for historical research, the "desire for historical reality","1 we should note that this desire is only part of the story: as self-reflection is only a part of the feeling of agency, so motivation and intention are only part of the process of historical representation. Of course, since Gumbrecht wrote this essay, the "direct experience of the past"12 (which the desire for historical reality is ultimately directed at) has become an extremely fashionable topic even among theorists of history and history culture. ${ }^{13}$ It might indeed now be safe to say that acknowledging historians' (and some theorists') "desire" for presence is not enough in compensating for the problems with the turn to entertainment. What needs to be done, rather, is to examine the needs underlying this 
desire for presence, experience, or re-presentation. This can, to me, be most usefully addressed in terms of self-reflection and agency. This is where the difficulties with irony and entertainment may be better dealt with.

\section{6}

Contemporary irony as it appears in political practice and its reception can quite usefully be viewed as a perversion of the poststructuralist dictum to always question. Whether there is a direct relation between these phenomena or not, it is clear that the textualist variant of poststructuralism with its emphasis on play is something that has practical parallels in many areas, not only in political rhetoric and certainly not only within literary studies and the humanities. Indeed, this kind of "play" would seem to mark most of our contemporary attitudes. Having said this, there is an important distinction that needs to be made between irony in this sense and relativism or epistemological scepticism as presented by poststructuralist theory: irony and relativism in its popular manifestation can easily become hedonistic and self-serving. Prevalent attitudes seem not to reflect a spirit of critique but rather offer opportunities for the dismissal of politically unwelcome alternatives and the concentration of power with those who already exercise it.

In contrast, poststructuralist philosophy presents a form of relativism that is ethically committed. Which, that is, is not afraid to prescribe. The foundation of this form of relativism lies in a suspicion of representational practices in toto. Indeed, representation is seen as a last resort, engaged in only when the potential benefits of representing outweigh potential harm. ${ }^{14}$ While this kind of vague principle is highly problematic and begs clarification from those looking for a rule to live by, the point is no less salient: if we simply give attention to weighing the pros and cons as we act, we will already have assumed responsibility for our actions.

Awareness of responsibility is as far as poststructuralist theory can take us when examined rigorously, yet that should be more than enough.

It is with regard to the details of sense-making that we might learn from historians. Where consumers of history turn to its capacity for entertainment, historians seek similar satisfaction in a different way. From an idealised and abstract vantage point, historians would appear to be somewhat sad people. Underlying their work is a continuing desire for experience and contact, a never-satisfied phenomenological yearning (the very same "desire for presence" that Gumbrecht points to). ${ }^{15}$ The constant comparison of history to literature by theorists only serves to feed this desire with its emphasis on experience, reality and "presence" in one form or another. What needs to be done, then, is to find other ways of satisfying this desire for significance. Objectivity and the consequent assumed contact with reality simply are not viable options. And - as I hope to have already suggested - nor is the creation of emotions through consumption; the presentation of the past in ways intended to "move" and "touch" on the basis of their evoking easily recognisable and often somewhat excessive attitudes in readers. Instead, the stir and disturbance 


\section{Critical Historiography in the Entertainment Age}

created in readers by representations that cater to this desire should be seen for what they are: sublimations of the actual disruption or disjuncture glossed over with the kind of narrative that re-presents reality as appealing story.

The sense of significance that historians go to the past to find can, to me, be best examined in terms of agency. Or simply - and perhaps a little unfairly - as disappointment or disillusionment with their experience of reality, even as an absence of contact with "life". (Think of the stereotype of the fuddled historian in the archive.) But what about theorists, then? The ones who cannot find that sense of significance in history, who come away from reading histories, let alone historical documents, with a parallel sense of disappointment? Again, attending to agency seems to help here. Obviously we all want what we do to feel significant and the experience of agency is crucial in ensuring just that. For "objectivist" historians and the rest of us, however, there is a marked difference in what that agency is directed at, and from what it thus receives its confirmation and existence. The imagination these ideal historians possess - the "historical imagination"16 - is of a totally different kind: theirs is a traditionally scientific interest, engaging with puzzles and investigation for the sake of it. Because the past is real and there is a truth "out there" - even if it is obviously too complex to capture or comprehend - historians have a clear objective beyond, or, to be precise, (at least logically) antecedent to, representational practice. The imagination and agency guiding the process of representation, on the other hand, is productive and forwardoriented, not interested in puzzles but in form and effects. Significance here is much more dependent on communication and approval. So, for "the historian" (someone primarily exercising that particular kind of historical imagination), agency is felt in a relatively self-sufficient way, the past provides a locus for its exercise independent of achievable effects. Others among us, however, view the past as a closed domain, with no room for interaction; hence experiencing agency requires more feedback than that provided by conversing with an imaginary subject (or, more specifically, a subject whose answers in the hermeneutic process are (re)constructed in and by the imagination of the historian). Sense of agency comes, instead, from acting on the world we inhabit in our daily lives.

\section{8}

Having said all this, it needs to be pointed out that these objectivist historians - caricatured though they obviously are - seem to have the right end of the stick in one essential respect: History puts us face to face with another (an external agent) in a very particular way: although absent and unavailable to experience, the other is not abstract or imaginary in the sense it is in cinema, literature and philosophy, for instance. It is thus tempting to claim that history can jar us out of self-reflection in a purely private mode, forcing us to recognise both the nonsameness of the other to ourselves as well as the nonidentity of that otherness in terms of internal coherent, continuous - or even contiguous - and determinable or fully exhaustible subject positions. ${ }^{17}$ Like the world in general, we are all intricate and inappropriable, and history - by which I mean representations committed to reality albeit with all the necessary caveats - shows this better than any other representational form; in part because it simultaneously denies communication. 
Conversely, the reason that films and novels, even quite bad ones, manage to hijack the imagination so effectively, results - at least for me - from the aesthetic and moral closure they effect. ${ }^{18}$ They leave little room for doubt, and, instead of presenting us with the other, they set us face to face with ourselves. In disturbing this moral closure, history - historical materials - can also be used to counter the ideological tendencies of narrative. Importantly, this is something that historians can do by going with the grain and nature of their passion with the past instead of trying to imitate representational strategies designed for other genres. ${ }^{19}$

If this is true, if history is thus quite special in this way, what of the poststructuralist denial of representational practices? Doesn't history sound much too desirable to be rejected on principle alone? In resolving this dilemma, theorists could, of course, simply take a page from Richard Rorty's book and apply his argument concerning literature and philosophy to the writing of history. He writes: "The pursuit of private perfection is a perfectly reasonable aim for some writers ... Serving human liberty is a perfectly reasonable aim for other writers ... There is nothing called 'the aim of writing' any more than there is something called 'the aim of theorizing'. "20 Or indeed, we might continue, the "aim of history". Importantly, even Rorty does not say that it is desirable to aim at nothing, however.

But what would this mean for a critical historiography? Should we leave justification for its existence to individual whim? Is critical historiography needed at all? (If it were intended as anything other than rhetorical, this question would have been asked at the beginning, of course.) Do historians have responsibilities for the world as historians or can they simply concentrate on doing their work, whether the goal of that work is institutionally defined as the search for "truth" and knowledge or as the entertainment and amusement of readers? The short answer, to me, is fully in line with the existentialist and poststructuralist ethic: we are all equally responsible (or equally culpable). The responsibilities of individuals are only magnified in their work when it influences the attitudes of others as it does in the case of historians. If and where the linguistic turn has made it impossible to hide behind veils of objectivity and method, it has brought this ethic to the fore. And if the only goal more objectively thinking historians can point to is the grudging admission that history brings meaning to their lives by fulfilling a desire for the real (not only through the fictional covering over of the linguistic abyss but also in the understanding and sense of significance achieved), we should follow up on this as theorists. (Sadly the historian's decision to get on with history and "understand" ultimately fails: a historian's understanding is always incomplete since the past does not speak back. In this way the historical imagination easily becomes, for me, a self-indulgence as there is no affirmation of and no consequence to the communication - which is not to judge this kind of work as necessarily a private pursuit.)

So, the critical attitudes we need to develop go beyond source criticism and fidelity to professional practices. ${ }^{21}$ They will also have to sidestep some of the issues that the debate concerning representational form most often raises. History - or the realisation of any critical historiography 


\section{Critical Historiography in the Entertainment Age}

- will need to find strength in its epistemological concreteness while, at the same time, recognising the fact that "the truth" is unattainable. In this, the role of representation regarding content needs to be admitted and studied in depth, but representation should at the same time be distinguished from a purely linguistic and literary process of meaning-construction. (Which is not to say that we can ever have access to meaning "behind" texts but rather that we can utilise parallel situations and understandings in a going "beyond" of the text. For instance, when we read a poem, we need not - even in our role as historians - be limited to systematic decoding of textual references, clues and structures but can also appreciate the physical and emotive responses it evokes, even to the extent of factoring these into our interpretation without fear of anachronism.)

While this may all sound like a digression from the question of what critical historiography can be, the importance of this kind of responsiveness should not be too hastily dismissed. It is not, after all, sensible to exclude intuitions from any "play" as long as that particular play is intended to involve something more than highly intellectualised word games. Instead, critical historiography needs to incorporate the whole scope of being human in its interpretive and communicative processes. And this entails still a further broadening in scope: appealing to the intentions behind a representation has been thoroughly discredited by textualist theory, especially in its more literary-oriented forms. It has been said that there is no reason to go "beyond" a text to search for meaning, and this has been, by and large, accepted by textualist theorising of history too. But this is not the direction that emphasis on linguistic construction needs to point us in. Instead, intentions (as provisional end-points to interpretive chains) can be recognised. ${ }^{22}$ More importantly, the obstacles historical materials create can also be accepted as indicators of contact with reality. Indeed, communication is possible in history only by foregrounding the "reality" and concreteness of history, and sense of purpose can be found only in a feeling of agency that is neither from the past nor present alone but from the disjuncture and discomfort of attempting to deal respectfully with both.

The "lesson" history teaches us is thus fundamentally that of respect. While this is a lesson we are faced with daily in pragmatic endeavours - the basics of a Levinasian ethics and the encounter with another - such confrontation is absent from the reflective, linguistic-discursive world of academia, for instance. And without reminders, our intellectual discourse easily turns into "play" and entertainment.

\section{0}

To me, as I am sure for pretty much everyone, the impact of historical thinking on the opportunities of people living today should be central to any definition of critique in historical representation. (And I know this has been said many times over by many people, but it remains a fundamental point of departure in my mind and cannot be emphasised enough.) As Beverley Southgate eloquently argues, the answer to the question "What is history for?" can best be answered in terms of the removal of exclusive and limiting (oppressive) structures - with exclusion and dogmatism rather than imagination being the opposites of science. History's being for can thus be seen in terms of its "therapeutic function" for the individual and its moral use at the level of society. ${ }^{23}$ 
At the same time, seeing history more as communication than representation would permit a significant rethinking of the current controversy between the historical imagination and pragmatic interests. Further, a full recognition of the study of the past as a paradoxical communication without a subject would make more obvious the nature of history as self-reflective and future-oriented. This is clouded by the current emphasis on history as being "like literature", as representation without an object; the epistemological difficulties of studying the past do need to be kept in mind, but continuing to emphasise the arbitrariness of interpretations in a situation where linguistic constructivism is already largely accepted only serves to prevent even that "provisional halt to the process of interpretation" that Bevir suggests we allow for - despite whatever theoretical discomfort this can cause. Postfoundationalist justifications for history need to be found in praxis, in terms of the tentative assumption that we do, after all, understand each other (as well as those paradoxical absent subjects) to an extent that makes communication possible. For history (as opposed to the study of the past) this means we need to recognise that communication should have a subject and that subject needs to be taken into consideration in the arenas where it matters, not only in the shared ironic amusement we find in the "play" of readings and in entertaining representations. It also means that we need to see that not only are all our engagements with the world equally linguistically constructed and thus subject to parallel epistemological problems but that, despite this, history too must be kept among the vehicles of critical engagement. And, finally, that this is what we need historical theory for.

\section{NOTES}

1 Mark Bevir, "How to be an Intentionalist", in Gabrielle M. Spiegel (ed.), Practicing History: New Directions in Historical Writing after the Linguistic Turn, New York/London: Routledge, 2005, 166-75 (170).

2 Even then, the goal of accurate representation - the "historian's promise" - remains a central though problematic definition of the genre. See, for example, Alun Munslow, Narrative and History, Basingstoke/New York: Palgrave Macmillan, 2007, 124.

3 See, for example, Gabrielle M. Spiegel, "Introduction", in Spiegel (ed.), Practicing History, 1-31.

4 See, for example, Stephen Davies, Empiricism and History, Basingstoke/New York: Palgrave Macmillan, 2003.

5 Hans Ulrich Gumbrecht, In 1926: Living at the Edge of Time, Cambridge/London: Harvard UP, 1997, 411.

6 For more on White's rescue of history, see, for example, Kalle Pihlainen, "History in the World: Hayden White and the Consumer of History", Rethinking History 12:1 (2008): 23-39.

7 Indeed, as Keith Jenkins suggests, even theorists might play their part in this. We could well decide to "live amidst the ample and agreeable imaginaries provided by postmodern-type theorists, ... theorists who can generate enough by way of emancipatory rhetorics such that we no longer need any kind of foundational - or non-foundational - past." See Keith Jenkins, "'After' History", Rethinking History 3:1 (1999): 7-21 (10).

8 For a concise presentation of this position, see, for example, Keith Jenkins, "The End of the Affair: On 


\section{Critical Historiography in the Entertainment Age}

the Irretrievable Breakdown of History and Ethics", Rethinking History 11:2 (2007): 275-85.

9 Hayden White, Figural Realism: Studies in the Mimesis Effect, Baltimore/London: Johns Hopkins UP, 1999.

10 Gumbrecht, In 1926, 423-24.

11 ibid., 417-18.

12 Ibid., 419.

13 This is well illustrated by the October 2006 issue of History and Theory. See in particular Eelco Runia, "Presence", History and Theory 45:1 (2006): 1-29, and Michael Bentley, "Past and 'Presence': Revisiting Historical Ontology", History and Theory 45:3 (2006): 349-61.

14 See, for example, Todd May, The Moral Theory of Poststructuralism, University Park: Pennsylvania State UP, 1995, 49 and passim. While many people might question such an interpretation of poststructuralism, I find it quite convincing.

15 As I understand Gareth Stedman Jones' claims, this desire, which I've dubbed the historian's phenomenological yearning, is comparable to what he intends by the "determinist fix" that historians continue to crave. At least it similarly highlights the materialist underpinnings of historical work at the level of personal involvement with the past and with history in terms of a subjective need. See Gareth Stedman Jones, "The Determinist Fix: Some Obstacles to the Further Development of the Linguistic Approach to History in the 1990s", in Spiegel (ed.), Practicing History, 62-75 (62 ff).

16 And by this I refer only casually to the use of the term by R.G. Collingwood and Owen Barfield, for example. The kind of stripping away of historical layers influencing our readings of the past is an admirable ideal, but can still only ever result in approximation. What I intend by the "historical imagination" here thus points to a frame of mind rather than any systematic methodology or theory.

17 Another clarification is in order: While there is an obvious affinity between such arguments and a hermeneutic "merging of horizons", I do not wish to follow that metaphor because of the strong connotations it has of a truth "out there" - albeit lost in the past - as opposed to a multitude of subjective and irreconcilable (as well as naturally) unrecoverable truths held by diverse agents in the past.

18 This point has been famously made by White. See, for example, Hayden White, The Content of the Form: Narrative Discourse and Historical Representation, Baltimore/London: Johns Hopkins UP, 1987, 23.

19 For more on this, see, for example, Kalle Pihlainen, "On History as Communication and Constraint", Ideas in History 4:2 (2009): 63-90.

20 Richard Rorty, Contingency, Irony, and Solidarity, Cambridge: Cambridge UP, 1989, 145.

21 At the same time, with so much attention having gone to the more extreme interpretations of constructivism so far, it is crucial to emphasise the importance of holding on to the professional criteria we have for evaluating histories. There is no reason to become uncritical in this very basic sense, a point that Hayden White has insisted on from the start, despite interpretations to the contrary by enthusiastic participants on both sides of the fact-fiction debate. See, for example, White, The Content of the Form, 45.

22 Cf. Bevir, "How to be an Intentionalist", $166 f f$.

23 See Beverley Southgate, What is History For? London/New York: Routledge, 2005, 6ff. 
01 History and Semiotics

02 Heterodoxies:

Constructions of Identities and Otherness

03 European Ego-histoires

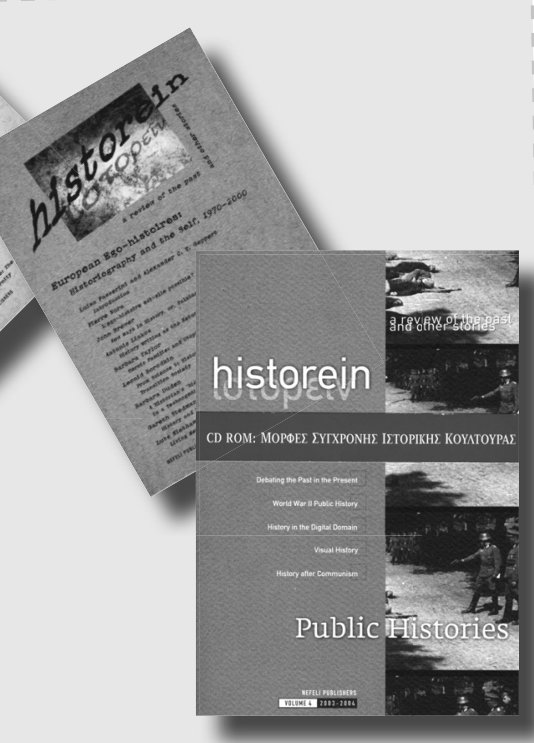

04 Public Histories

\section{histgrein \\ a review of the past and other stories}

05 Empires

06 Religions in Conflict

07 History and Utopia

08 Performing Emotions Historical and Anthropological Sites of Affect 09 Historising 1968 and the Long Sixties

NEFELI PUBLISHERS

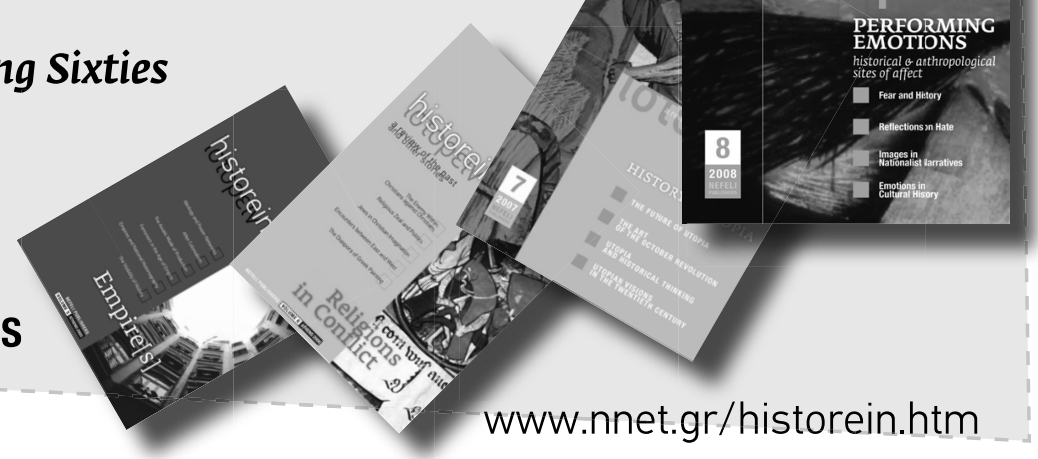

